\title{
SIGNIFICANCE OF STUDENTS ' PHYSICAL ACTIVITY
}

\author{
(C) 2020 Voikina Diana Vladimirovna \\ Student \\ (C) 2020 Nalimova Marina Nikolaevna \\ Senior lecturer \\ Samara State University of Economics \\ E-mail: vojjkina-diana@rambler.ru
}

Keywords: healthy lifestyle, students, University, physical activity.

This article discusses the importance of physical activity of students of higher education institutions. Modern diseases that occur quite often in University students are analyzed,as well as the priority of physical training. A sample is being conducted for students of Samara state University of Economics.

УДК 796

Код РИНЦ 77.00 .00

\section{ИССЛЕДОВАНИЕ ВЛИЯНИЯ СОСТОЯНИЯ ЛИМФАТИЧЕСКОЙ СИСТЕМЫ НА ЗДОРОВЬЕ ЧЕЛОВЕКА}

\author{
(C) 2020 Вотинова Татьяна Александровна* \\ студент \\ Самарский государственный экономический университет \\ E-mail: Tanya_Votinova@mail.ru
}

Ключевые слова: лимфатическая система, иммунная система, внутренняя среда организма, сердечнососудистая система, профилактика заболеваний, физическая активность.

Современные люди, заботящиеся о своем здоровье, должны интересоваться такой уникальной системой, как лимфатическая система, и знать о ее значении в жизни человека. Лимфатическая система - одна из самых интересных и сложных систем в организме. Это система для выведения токсинов, а также бактериальных и грибково-паразитарных ядов, образующихся из микроорганизмов, пришедших из внешней среды. Иммунная система человека практически зависит от этой системы. А иммунитет - самая важная составляющая успешной жизни.

Лимфа - это составляющая крови, лимфатическая система проходит сквозь всю структуру организма через свои тончайшие капилляры. Основные функции лимфатической системы состоят в следующем:

- проведение лимфы от тканей в вены,

- всасывание из межклеточного пространства коллоидных растворов белковых веществ, которые не всасываются в кровеносные капилляры, цент.

* Научный руководитель - Николаева Ирина Валерьевна, кандидат педагогических наук, до- 
- всасывание воды (растворенных в ней кристаллоидов),

- образование лимфоцитов, необходимых для иммунологических процессов,

- обезвреживание инородных частиц, бактерий и микробов, попадающих в организм.

Лимфа - это молочно-белая жидкость, по составу схожая с плазмой крови, но содержание белка в лимфе в 3-4 раза меньше. В составе главным образом содержатся лимфоциты, а также лейкоциты. Скорость движения лимфы в крупных лимфатических сосудах составляет 0,25 - 0,3 мм/с (15 мм/мин).

В состав лимфатической системы, в соответствии с выделенными функциями, входят: лимфокапилляры, лимфатические сосуды, стволы, протоки и лимфоузлы в слизистых оболочках, где происходит образование и развитие лимфоцитов.

Для построения и жизнедеятельности клеток организма необходимы питательные вещества, а также кислород, которые поступают через ткани внутренних органов. Одновременно происходит процесс естественного отмирания клеток (около 1 млрд. в сутки). Иммунная система справляется с попадающими в организм вирусами и бактериями. Для вывода токсинов необходима лимфатическая система.

Таким образом, основное предназначение лимфы состоит в том, чтобы смывать через лимфатические капилляры и протоки бактерии, вирусы и токсины, попавшие в организм, а также погибшие в результате жизнедеятельности организма клетки1.

Основная часть шлаков (до 80\%) находится в межклеточной жидкости, которой может быть до 40 литров. Необходимо прочищать всю эту застоявшуюся воду.

Движение лимфы осуществляется посредством сокращения лимфатических узлов, либо мышц, расположенных вдоль лимфатических протоков. Поэтому можно говорить, что отток лимфы ухудшается при малоподвижно образе жизни, а также при нарушении фрункций нервной системы. Результатом нарушения лимфооттока, т. е. последствиями интоксикации лимфатической системы, является:

- образование угревой сыпи (выход токсинов через кожные покровы);

- неприятные запахи (окисление задерживающихся в кожных покровах токсинов);

- пигментные пятна, папилломы и другие кожные образования.

Всевозможные отеки - это также застоявшаяся лимфатическая жидкость. Большинство людей относит воспаление суставов, отеки ног, болезни бронхов и легких к сердечной или почечной недостаточности. Однако отек ног зачастую означает застой паховых лимфоузлов, рук - подмышечных, глаз - лицевых, а всего одновременно - о закупорке почек.

Блокировка распространения инфекции происходит так: вирусы, бактерии и грибки, попадая в организм, встречаются с лейкоцитами, либо "заглатывающими" бактерии, либо выталкивающими их в лимфоузлы, где они рассасываются и выбрасываются обратно.

До 50\% ядов, выводимых организмом, выходит через подмышечные впадины. Антиперспиранты закрывают протоки потовых желез, и пот не выделяется. А это главный "дренаж" от молочных желез. Если он забит, застой токсинов в тканях молочных желез приводит к мастопатии. На лице расположено немного потовых желез, поэтому если в спокойном состоянии потеет лицо, это указывает на застой лимфатической системы.

Если человек потеет во сне, это означает интоксикацию (чаще паразитарную). Дети не должны потеть, так как у них слабо развита потовая система, и токсины выводятся через почки и кишечник. 
По своей структуре сильно засоренная лимфа представляет собой густой гель. Нормальная же лимфа - жидкая (золь). Хорошей тренировкой лимфатической системы является сауна: лимфра разжижается, начинает течь, через потовые железы выходит пот, от холодной воды железы закрываются. Также разжижить лимфу помогают лимфостимуляторы, такие как: листья смородины, корень солодки, шиповник, тысячелистник, овес и т.д. Для эфффективной прочистки лимфы, ее нужно разжижать, постоянно дополняя чистой водой. Движение лимфы происходит снизу вверх. По этой причине массаж и любые растирательные движения необходимо делать в этом же направлении.

При разжижении лимфы разжижается мокрота, ее необходимо отхаркивать, начинается промывание межклеточного пространства, происходит выброс в лимфу ядов, которые выводятся с потом через поверхность кожи и в полость кишечника через узлы кишечника. Яды с кожи необходимо промыть сначала горячей, а потом холодной водой. Дезинтоксикация происходит также через слюнные железы. Посредством слюны выходит до 0,5 л жидкости с токсинами.

Для наиболее полного понимания значения лимфатической системы, не будет лишним отметить недавно полученные результаты исследований шведских ученых из Каролингского института ${ }^{5}$, свидетельствующие о существовании механизма, при помощи которого раковые клетки проникают в лимфатическую систему, а затем перемещаются по организму для образования метастаз (вторичных злокачественных опухолей). В статье сообщается, как раковые клетки становятся внешне похожими на иммунные, причиной является воспалительный белок TransformingGrowthFactor-beta-1 (трансформирующий фактор роста-бета). Далее TGF- $\beta 1$ связывается с рецепторами лейкоцитов - участников иммунной системы, неразрывно связанной с лимфой. Решение данной проблемы врачи находят в противовоспалительных препаратах, сдерживающих распространение злокачественных опухолей 4 .

Таким образом, можно остановиться на следующих аспектах о лимфатической системе, выражающих ее влияние на состояние здоровья человека:

1. Лимфатическая система способствует оттоку лишней жидкости из тканей.

2. Лимфа - это молочно-белая жидкость, по составу схожая с плазмой крови, но содержание белка в лимфе в 3-4 раза меньше. В составе главным образом содержатся лимфоциты, а также лейкоциты.

3. Скорость движения лимфы гораздо ниже, чем крови.

4. В сутки в кровь возвращается около 1 - 3 л лимфы.

5. В лимфатических узлах происходит обезвреживание чужеродных веществ.

6. На нормальное функционирование функций лимфатической системы положительно влияют занятия спортом, фризической культурой, соблюдение личной гигиены, режима питания, гигиена дыхания и нормальная работа кровеносной системы. Любые активные движения ведут к профилактике застоя лимфы. Сегодня чрезвычайно важным элементом в сфере физической культуры и спорта является инновационная деятельность. Благодаря инновационным технологиям, происходит активная агитация всего населения к ведению здорового образа жизни и тем самым к укреплению их здоровья.

1 В.И. Коненков, Ю.И. Бородин, М.С. Любарский. ЛИМФОЛОГИЯ. Издательский дом "Манускрипт".Новосибирск. - 2012 . С. 17-21; 
2 ПетренКо В.М. ЛИМФАТИЧЕСКАЯ СИСТЕМА И ЕЕ МЕСТО В ТЕЛЕ ЧЕЛОВЕКА // МежДУНародный журнал прикладных и фундаментальных исследований. - 2016. - № 4-5. - C. 917-921; URL: https://applied-research.ru/ru/article/view?id=9103

3 Петренко В.М. Лимфология как медико-биологическая наука: современные представления в России и история их формирования // Научное обозрение. Мед. науки. - 2016. - № 2. - С. 84-90.

${ }^{4}$ Catharine Paddock, Ph.D. Cancer cells 'disguise themselves as immune cells' to spread via lymphatic system, study finds, May 12, 2015 URL: https://www.medicalnewstoday. com/articles/293745

${ }^{5}$ Pang, M., Georgoudaki, A., Lambut, L. et al. TGF- $\beta 1$-induced EMT promotes targeted migration of breast cancer cells through the lymphatic system by the activation of CCR7/CCL21-mediated chemotaxis. журнал Oncogene, издательство Nature Publishing Group (United Kingdom), том 35, с. 748-760 (2016). URL: https://doi.org/10.1038/onc.2015.133

\title{
INNOVATIVE ACTIVITIES IN THE FIELD OF PHYS ICAL CULTURE AND SPORTS
}

\author{
(C) 2020 Votinova Tatyana Alexandrovna \\ Student \\ Samara State University of Economics \\ E-mail:Tanya_Votinova@mail.ru
}

Keywords: the lymphatic system, the immune system, the internal environment of the body, the cardiovascular system, disease prevention, physical activity.

Modern people who care about their health should be interested in such a unique system as the lymphatic system and know about its significance in human life. The lymphatic system is one of the most interesting and complex systems in the body. This is a system for removing toxins, as well as bacterial and fungal-parasitic poisons formed from microorganisms that have come from the external environment. The human immune system practically depends on this system. And immunity is the most important component of a successful life.

УДК 796

Код РИНЦ 77.05.00

\section{ГИПОДИНАМИЯ - БИЧ ХХІ ВЕКА}

(C) 2020 Габбасова Ирина Маратовна*

студент

Самарский государственный экономический университет

Email: gabbasova.o@mail.ru

Ключевые слова: здоровье, гиподинамия, малоподвижный образ жизни, Всемирная организация здравоохранения.

* Научный руководитель - Николаева Ирина Валерьевна, кандидат педагогических наук, доцент. 